\title{
EFEKTIVITAS PEMBERIAN EKSTRAK BIJI KETUMBAR TERHADAP GAMBARAN SEL BUSA ATEROSKLEROSIS AORTA ABDOMINALIS TIKUS HIPERKOLESTEROLEMIA DIABETES
}

\author{
Kusvandita Giopratiwi ${ }^{1}$, Maria Selvester Thadeus ${ }^{2}$, Retno Yulianti ${ }^{3}$ \\ ${ }^{1}$ Program Studi Kedokteran Program Sarjana, FK UPN Veteran Jakarta \\ Email: kusvandita0310@gmail.com \\ ${ }^{2}$ Departemen Patologi Anatomi, FK UPN Veteran Jakarta \\ Email: maria_fkupn@yahoo.co.id \\ ${ }^{3}$ Departemen Patologi Anatomi, FK UPN Veteran Jakarta \\ Email:dr.retnoyulianti@yahoo.com
}

Masuk: 23-06-2020, revisi: 27-08-2020, diterima untuk diterbitkan: 30-09-2020

\begin{abstract}
ABSTRAK
Ekstrak biji ketumbar (EBJ) diduga memiliki potensi untuk memperbaiki proses pembentukan sel busa lesi aterosklerosis. Penelitian ini bertujuan untuk mengetahui efektivitas pemberian ekstrak biji ketumbar terhadap gambaran histopatologi sel busa aterosklerosis aorta abdominalis tikus model hiperkolesterolemia diabetes. Penelitian dilakukan selama 63 hari. Sebanyak 30 ekor tikus Galur Wistar outbred dibagi ke dalam 5 kelompok, masing-masing kelompok terdiri dari 6 ekor. Kelompok kontrol negatif (pakan standar), kelompok kontrol positif (pakan tinggi lemak dan aloksan + glibenklamid $0.045 \mathrm{mg}$ ), kelompok perlakuan 1 (pakan tinggi lemak dan aloksan + EBJ $300 \mathrm{mg} / \mathrm{kgBB} / \mathrm{hari}$ ), kelompok perlakuan 2 (pakan tinggi lemak dan aloksan + EBJ $500 \mathrm{mg} / \mathrm{kgBB} / \mathrm{hari}$ ), dan kelompok perlakuan 3 (pakan tinggi lemak dan aloksan + EBJ $700 \mathrm{mg} / \mathrm{kgBB} / \mathrm{hari}$ ). Setelah perlakuan, dilakukan pembedahan dan pengambilan organ aorta abdominalis lalu dibuat preparat untuk menilai gambaran sel busa. Analisis statistika dengan Uji One Way ANOVA dan uji Post Hoc Bonferoni menunjukkan ada perbedaan signifikan $(P$ Value $=0.049)$ antara kelompok kontrol positif dengan kelompok perlakuan 3. Kesimpulannya, EBJ dosis 700 $\mathrm{mg} / \mathrm{kgBB} /$ hari memiliki efektivitas untuk menurunkan pembentukan sel busa dalam proses aterosklerosis.
\end{abstract}

Kata Kunci: aterosklerosis; ekstrak biji ketumbar; hiperkolesterolemia; sel busa

\begin{abstract}
Coriander Seed Extract (CSE) is thought to have the potential to repair foam cell formation process which is part of atherosclerotic lesion. The aim of this study is to identify the effects of coriander seed extract on histopathological features of atherosclerotic foam cells abdominal aorta in rats hypercholesterolemia diabetes model. The study was conducted for 63 days. 30 Wistar outbred rats were grouped into five groups, each group consist of 6 rats. Negative control group (standar feed), positive control group (high fat diet and alloxan + glibenclamide 0.045 mg), treatment group 1 (high fat diet and alloxan + CSE $300 \mathrm{mg} / \mathrm{kgBB} /$ day), treatment group 2 (high fat diet and alloxan + CSE $500 \mathrm{mg} / \mathrm{kgBB} /$ day), treatment group 3 (high fat diet and alloxan + CSE $700 \mathrm{mg} / \mathrm{kgBB} /$ day). After the treatment were given to each group, the next procedure were dissection, extraction of the aorta abdominal organ, and histopathological examination of foam cell. Data were analyzed with One Way ANOVA test and Post Hoc Bonferoni test show there are significant difference $(P$ value $=0.049)$ between positive control group and treatment group 3. In conclusion, CSE $700 \mathrm{mg} / \mathrm{kgBB}$ dose can reduce foam cell formation.
\end{abstract}

Keywords: atherosclerosis; coriander seed extract; foam cell; hypercholesterolemia. 


\section{PENDAHULUAN}

\section{Latar Belakang}

Perubahan pola hidup yang terjadi pada masyarakat Indonesia seperti banyak mengonsumsi makanan yang berlemak dan manis, kurangnya aktivitas fisik atau olahraga, dan merokok dapat mempengaruhi perubahan pola penyakit di Indonesia (Frankilawati, 2013). Terdapat peningkatan kejadian Penyakit Tidak Menular (PTM) seperti obesitas, hipertensi, dan diabetes yang menjadi penyebab kematian secara global (Kristiawan P. A., 2019).

Diabetes Melitus (DM) merupakan suatu gangguan metabolik yang ditandai dengan kenaikan gula darah akibat defek sekresi hormon insulin oleh sel beta pankreas, gangguan fungsi hormon insulin atau keduanya (Bhatt, Saklani dan Upadhayay, 2016). Menurut International Diabetes Federation (IDF) (2017) tahun 2017 disebutkan bahwa sekitar 425 juta orang dewasa di dunia mengalami DM dan akan meningkat menjadi 629 juta orang dewasa menderita penyakit DM. Negara Indonesia menduduki urutan ke 6 di dunia dan akan menjadi urutan ke 5 di tahun 2025. Dari beberapa klasifikasi DM, sekitar 90-95\% kasus DM merupakan DM tipe 2. Penderita DM tipe 2 memiliki risiko timbulnya penyakit salah satunya adalah penyakit jantung koroner (Kharroubi, 2015).

Prevalensi Penyakit Jantung Koroner (PJK) di Indonesia tahun 2013 sebesar 1,5\% atau sekitar 2.650.340 orang dan risiko terjadinya akan terus meningkat seiring bertambahnya usia (Kementrian Kesehatan Pemerintah RI, 2014). Penderita DM memiliki risiko 2 sampai 4 kali lebih besar mengalami PJK (Lathifah, 2017). Penyakit jantung koroner merupakan suatu penyakit degeneratif yang disebabkan oleh proses aterosklerosis di pembuluh darah jantung yang akan menyebabkan penyumbatan aliran darah ke jantung (Tappi et al, 2019).

Aterosklerosis adalah peradangan pembuluh darah akibat adanya penimbunan lemak ekstrasel sehingga menyebabkan kekakuan dan penebalan pembuluh darah (Budiman et. al, 2017). Pembentukan aterosklerosis sering ditemukan di bagian proksimal arteri koroner yaitu arteri interventrikular anterior, proksimal arteri renalis, percabangan arteri karotis komunis, dan aorta abdominalis (Günenç Beşer et. al, 2016). Kelainan profil lipid atau dislipidemia merupakan salah satu faktor risiko utama penyebab aterosklerosis (Sorimuda, 2018).

Dislipidemia merupakan kelainan metabolisme lipid yang ditandai dengan peningkatan kadar kolesterol total, Low Density Lipoprotein (LDL), trigliserida, dan menurunnya kadar High Density Lipoprotein (HDL) (Nani, 2018). Kadar kolesterol yang berlebihan dapat memicu terbentuknya radikal bebas. Radikal bebas adalah molekul yang sangat reaktif dan dapat memicu terjadinya kerusakan jaringan sekitar. Stres oksidatif merupakan kondisi ketidakseimbangan antara radikal bebas dengan jumlah antioksidan dalam tubuh sehingga dibutuhkan antioksidan yang cukup dalam tubuh (Olivia Enggar, 2017).

Antioksidan dalam tubuh tidak memiliki cadangan berlebih sehingga saat radikal bebas banyak terbentuk dibutuhkan tambahan antioksidan eksogen. Antioksidan eksogen terdiri dari 
antioksidan sintetik dan antioksidan alami. Efek samping dari antioksidan sintetik belum banyak diketahui, sehingga antioksidan alami digunakan sebagai alternatif pengobatan. Antioksidan alami banyak ditemukan dalam bahan pangan seperti rempah-rempah, sayuran, buah, biji-bijian, dan teh (Sayuti, 2015). Salah satu tanaman rempah yang mengandung banyak zat antioksidan adalah ketumbar. Bagian dari tanaman ketumbar yang dapat dimanfaatkan adalah bijinya (Msaada et. al, 2017).

Tanaman ketumbar merupakan anggota dari familia Apiaceae dengan nama spesies Coriandrum sativum L. (Primanda, 2017). Biji ketumbar mengandung senyawa fenolik, flavonoid, dan tanin yang berpotensi sebagai antioksidan (Tianandari dan Rasidah, 2018). Senyawa fenolik dan flavonoid dapat menangkap radikal bebas dan memiliki efek hipokolesterol dengan menekan enzim HMG KoA sehingga dapat mengurangi biosintesis kolesterol total (Sari dan Rahayuningsih, 2014). Penelitian yang dilakukan oleh Nayereh Parsaeyan (2012) menunjukkan bahwa biji ketumbar terbukti dapat menurunkan kadar gula darah, dan memperbaiki profil lipid dalam darah dengan menurunkan kadar kolesterol darah, trigliserida, LDL, dan meningkatkan kadar HDL sehingga memungkinkan untuk mengatasi penderita DM tipe 2 dengan dislipidemia serta salah satu komplikasinya yaitu pembentukan aterosklerosis.

Berdasarkan latar belakang di atas yaitu peningkatan kasus DM setiap tahun serta PJK merupakan salah satu risiko penyakit akibat DM yang disebabkan oleh proses pembentukan aterosklerosis dan terdapat penelitian yang dapat membuktikan bahwa ekstrak biji ketumbar memungkinkan untuk mengatasi pembentukan aterosklerosis sehingga peneliti ingin mengetahui efek langsung yang terjadi pada gambaran histologik aorta abdominalis terhadap tikus putih yang telah diinduksi oleh aloksan dan pakan tinggi lemak lalu diberikan ekstrak biji ketumbar sebagai antioksidan. Peneliti tertarik untuk melakukan penelitian mengenai pengaruh dari biji ketumbar terhadap gambaran histopatologik sel busa aterosklerosis aorta abdominalis tikus model hiperkolesterolemia diabetes, sehingga hasil penelitian ini dapat digunakan sebagai pelengkap informasi bagi masyarakat ataupun penelitian selanjutnya.

\section{Rumusan Masalah}

Bagaimana pengaruh ekstrak biji ketumbar terhadap gambaran histopatologik sel busa aterosklerosis aorta abdominalis tikus model hiperkolesterolemia diabetes?

\section{METODE PENELITIAN}

\section{Desain Penelitian}

Penelitian menggunakan jenis penelitian eksperimental dan memakai desain penelitian true experiment dengan rancangan penelitian post test only control group design untuk gambaran histopatologik sel busa aterosklerosis. Pengambilan data sel busa dilakukan pada akhir penelitian setelah dilakukannya perlakuan dengan cara membandingkan hasil pada kelompok kontrol dengan kelompok perlakuan. 


\section{Populasi dan Sampel}

Populasi yang digunakan adalah hewan tikus putih (Rattus novergicus) Galur Wistar dan sampel penelitian yang dipilih tikus putih Galur Wistar jantan, berumur \pm 8 minggu, dan berat badan 180-200 gram.

\section{Pengumpulan Data}

Hasil perhitungan besar sampel menggunakan rumus Federer didapatkan bahwa sampel yang dibutuhkan tiap kelompok adalah 5 ekor tikus putih jantan. Pada penelitian ini dibutuhkan 5 kelompok perlakuan, dan untuk menghindari berukurangnya jumlah sampel akibat kematian pada saat perlakuan, maka setiap kelompok dipersiapkan untuk terjadinya drop out masingmasing kelompok ditambahkan 1 ekor tikus putih sehingga jumlah sampel total yang dibutuhkan dalam penelitian adalah 30 ekor tikus putih jantan Galur Wistar. Sumber data merupakan data primer yaitu dari 30 ekor hanya 25 ekor tikus putih yang diterminasi, diambil organ aorta abdominalis, dan diamati jumlah sel busa dibawah mikrokop dilakukan dibawah mikroskop cahaya dengan perbesaran 400x dilihat dan dilakukan penghitungan sel busa pada 9 lapang pandang (Ismawati et. al, 2017).

\section{Prosedur Penelitian}

Penelitian dilakukan setelah izin etik disetujui oleh Komisi Etik Penelitian Kesehatan Universitas Pembangunan Nasional "Veteran" Jakarta pada tanggal 28 November 2019 dengan nomor ethical approval B/2211/X/1019/KEPK. Penelitian diawali dengan pembuatan ekstrak biji ketumbar dengan pelarut etanol 95\% menggunakan metode maserasi (Yulianty et. al, 2015). Pembagian tikus putih menjadi 5 kelompok perlakuan dengan masing-masing kelompok terdiri dari 5 tikus putih. Aklimatisasi dilakukan selama 7 hari diawal penelitian. Kelompok kontrol negatif (K1) tikus diberi pakan standar Bravo-512; kelompok kontrol positif (K2) tikus diberikan glibenklamid $2.5 \mathrm{mg}$; kelompok perlakuan 1 (K3) tikus diberikan ekstrak biji ketumbar $300 \mathrm{mg} / \mathrm{kgBB} / \mathrm{hari}$; kelompok perlakuan 2 (K4) diberikan ekstrak biji ketumbar 500 $\mathrm{mg} / \mathrm{kgBB} / \mathrm{hari}$; kelompok perlakuan 3 (K5) diberikan ekstrak biji ketumbar $700 \mathrm{mg} / \mathrm{kgBB} / \mathrm{hari}$ (K6). Pada kelompok K2, K3, K4, dan K5 diberikan pakan tinggi lemak selama 5 minggu kemudian diinduksi aloksan $125 \mathrm{mg} / \mathrm{kgBB}$ intraperitoneal dan dilanjutkan kembali pemberian pakan tinggi lemak selama 4 minggu bersama pemberian glibenklamid pada kelompok K2 dan ekstrak biji ketumbar pada kelompok K3, K4, dan K5. Pemeriksaan kadar gula darah saat awal penelitian sebelum perlakuan dibandingkan dengan kadar gula darah setelah pemberian pakan tinggi lemak selama 5 minggu dan induksi aloksan $125 \mathrm{mg} / \mathrm{kgBB}$ dengan tujuan untuk mengetahui efektivitas dari pemberian pakan tinggi lemak dan aloksan berhasil untuk meningkatkan kadar gula darah tikus putih untuk dijadikan sebagai model hiperkolesterolemia diabetes. Setelah 63 hari penelitian tikus putih pada masing-masing kelompok perlakuan diterminasi dan dilakukan pengumpulan data. 


\section{HASIL DAN PEMBAHASAN}

\section{Hasil Analisis Bivariat}

\section{Pengaruh Ekstrak Biji Ketumbar dengan Rerata Jumlah Sel Busa}

Penelitian ini memiliki hasil berupa pengaruh ekstrak biji ketumbar terhadap gambaran histopatologik sel busa pada pembentukan lesi aterosklerosis aorta abdominalis tikus putih yang dijadikan model hiperkolesterolemia diabetes. Pada tabel 1 terdapat data rerata jumlah sel busa selama 63 hari penelitian.

Tabel 1. Rerata Jumlah Sel Busa

\begin{tabular}{lc}
\hline \multicolumn{1}{c}{ Nama Kelompok } & Rerata Jumlah Sel Busa \\
\hline K1 & $5.20( \pm 2.32)$ \\
\hline K2 & $15.74( \pm 3.56)$ \\
\hline K3 & $12.52( \pm 6.29)$ \\
\hline K4 & $13.82( \pm 8.34)$ \\
\hline K5 & $5.22( \pm 3.32)$ \\
\hline
\end{tabular}

Sumber tabel : Data Primer, 2020

Sesuai dengan hasil dari tabel 1, Kelompok kontrol negatif memiliki rerata jumlah sel busa terkecil sehingga dapat membedakan jumlah sel busa tikus yang normal dengan keempat kelompok perlakuan lainnya. Kelompok kontrol positif yang diberikan glibenklamid dan tidak diberikan perlakuan berupa pemberian ekstrak biji ketumbar memiliki jumlah rerata sel busa terbesar karena diberikan pakan tinggi lemak selama 9 minggu dan diinduksi aloksan. Kelompok perlakuan 1, kelompok perlakuan 2, dan kelompok perlakuan 3 mengalami penurunan rerata jumlah sel busa jika dibandingkan dengan hasil rerata jumlah sel busa pada kelompok kontrol positif. Kelompok perlakuan 3 merupakan kelompok yang paling banyak mengalami penurunan rerata jumlah sel busa.

\section{Pengaruh Ekstrak Biji Ketumbar dengan Gambaran Sel Busa}

Hasil penelitian berupa gambaran histopatologi aorta abdominalis yang telah dijadikan preparat dan diamati di bawah mikroskop kemudian diperhatikan dan dihitung pembentukan sel busa dari masing-masing kelompok preparat yang dapat dilihat pada gambar 1 sampai gambar 5 .

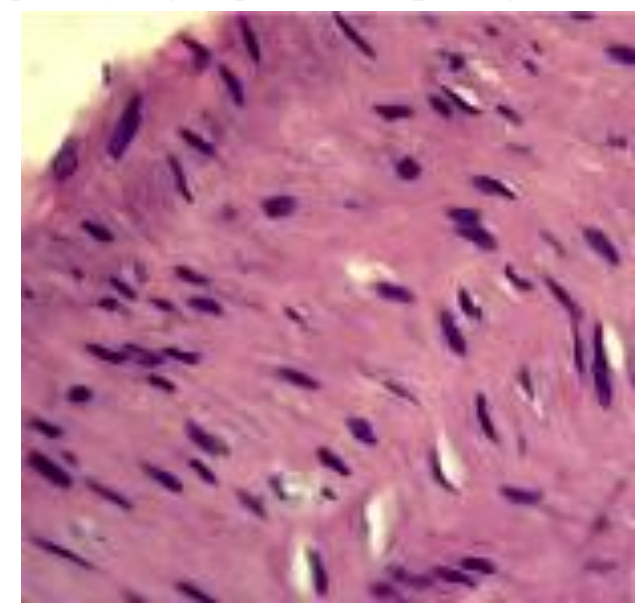

Gambar 1. Hasil Sajian Histopatologis Aorta Abdominalis Kelompok Kontrol Negatif Menggunakan Pewarnaan Hematoksilin dan Eosin Dengan Perbesaran 400x

Sumber Gambar : Data Primer, 2020 
Pada gambar 1 adalah hasil kelompok kontrol negatif yang memiliki rerata jumlah sel busa yang paling sedikit. yaitu $5.20( \pm 2.32)$ sehingga kelompok ini dapat dibandingkan dengan keempat kelompok perlakuan lainya. Sel busa diamati menggunakan mikroskop dengan perbesaran 400x dan dihitung setiap 9 lapang pandang dari masing-masing preparat, pada pewarnaan HE sel busa nampak sebagai sel besar dengan inti di tepi dan terlihat sebagai ruangan yang kosong gambaran seperti lemak (Ismawati et. al, 2017). Perbedaan bermakna berupa rerata jumlah sel busa aterosklerosis yaitu peningkatan rerata jumlah sel busa di kelompok kontrol positif yaitu 15.74 ( \pm 3.56$)$ hal ini didapatkan bahwa terdapat kerusakan aterosklerosis yang lebih banyak daripada kerusakan aterosklerosis di kelompok kontrol negatif.

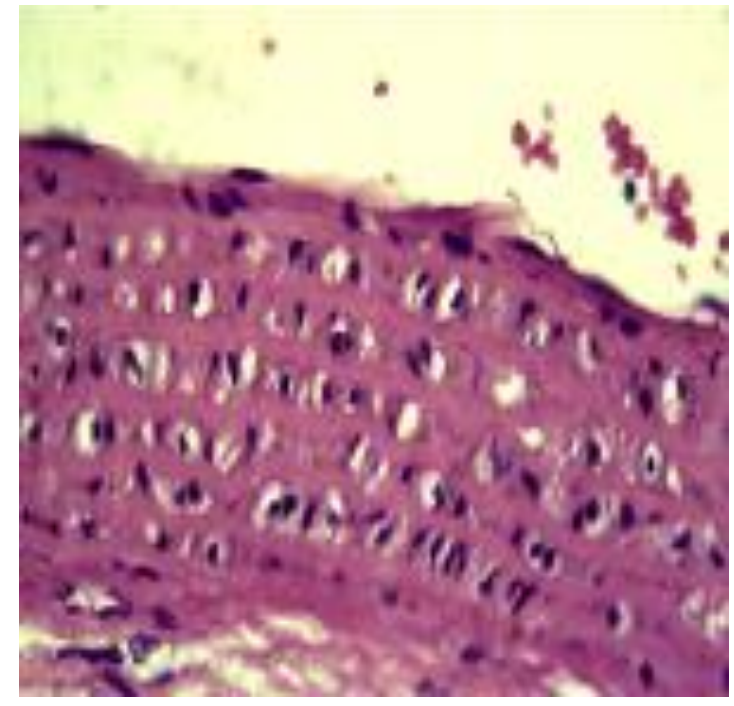

Gambar 2. Hasil Sajian Histopatologis Aorta Abdominalis Kelompok Kontrol Positif Menggunakan Pewarnaan Hematoksilin dan Eosin Dengan Perbesaran 400x

Sumber Gambar: Data Primer, 2020

Gambar 2 merupakan hasil kelompok kontrol positif. Pada pemeriksaan rerata jumlah sel busa pada kelompok kontrol positif memiliki jumlah sel busa paling banyak yaitu $15.74( \pm 3.56)$ dibandingkan pada keempat kelompok perlakuan lainnya. Hal ini dapat disebabkan karena pemberian pakan tinggi lemak yang sudah dilakukan selama 9 minggu terhadap tikus putih di kelompok perlakuan ini sehingga meningkatkan profil lipid sehingga menjadi faktor risiko pembentukan lesi aterosklerosis berupa sel busa. Proses pembentukan lesi aterosklerosis sehingga terbentuk sel busa diawali dengan akumulasi lipoprotein seperti LDL pada tunika intima yang menyebabkan masuknya lipoprotein LDL ke dalam pembuluh darah melewati endotel vaskular. Ketika LDL terakumulasi di ruang subendotel mengikat komponen matriks ekstraselular yaitu proteoglikan, sehingga terjadi "trapping" LDL di dalam tunika intima. Terjadi modifikasi kimia menjadi LDL yang termodifikasi (mLDL). Kemudian, stres oksidatif dan mLDL yang terbentuk mengaktifkan sitokin lokal. Sitokin yang aktif tersebut menyebabkan peningkatan ekspresi molekul adhesi yang mengikat leukosit dan molekul kemoatraktan berupa Monocyte Chemoattracttan Protein (MCP-1), sehingga leukosit dan monosit yang akan berubah menjadi makrofag bermigrasi ke tunika intima masuk ke dalam pembuluh darah. Makrofag yang sudah masuk akan membentuk reseptor scavenger menyebabkan pelekatan mLDL ke reseptor tersebut. Pelekatan mLDL tersebut juga merangsang otot polos dari tunika media bermigrasi ke tunika intima. Otot polos yang bermigrasi melekat bersama mLDL di reseptor scavenger semakin menumpuk membentuk sel busa (foam cell) (Lilly, 2011). 


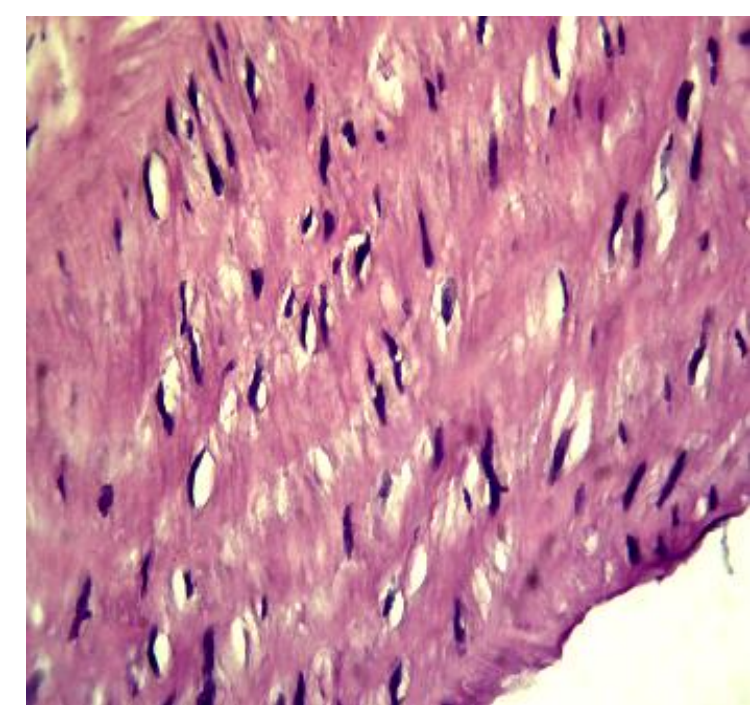

Gambar 3. Hasil Sajian Histopatologis Aorta Abdominalis Kelompok Perlakuan 1 Menggunakan Pewarnaan Hematoksilin dan Eosin Dengan Perbesaran 400x

Sumber Gambar: Data Primer, 2020

Gambar 3 adalah hasil kelompok perlakuan 1 yang diberikan ekstrak biji ketumbar dosis 300 $\mathrm{mg} / \mathrm{kgBB} / \mathrm{hari}$. Pada pemeriksaan rerata jumlah sel busa pada kelompok perlakuan 1 memiliki jumlah $12.52( \pm 6.29)$ sel busa, hasil ini memperlihatkan terdapat penurunan jumlah sel busa dibandingkan dengan jumlah sel busa pada kelompok kontrol positif. Ekstrak biji ketumbar 300 $\mathrm{mg} / \mathrm{kgBB} /$ hari mampu memberikan perbaikan terhadap jumlah sel busa pada lesi aterosklerosis di aorta abdominalis tikus putih.

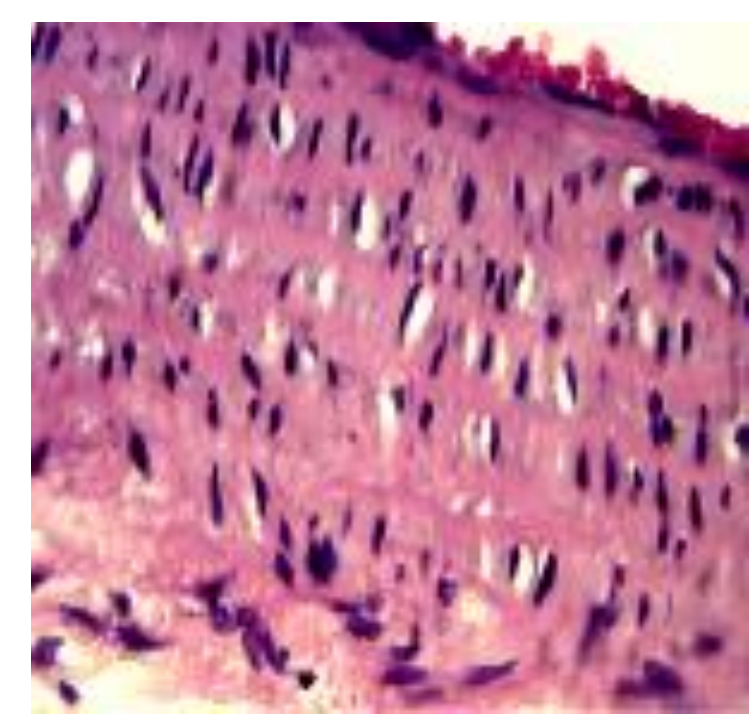

Gambar 4. Hasil Sajian Histopatologis Aorta Abdominalis Kelompok Perlakuan 2 Menggunakan Pewarnaan Hematoksilin dan Eosin Dengan Perbesaran 400x

Sumber Gambar: Data Primer, 2020 
Gambar 4 merupakan hasil kelompok perlakuan 2 yang diberikan ekstrak biji ketumbar dosis $500 \mathrm{mg} / \mathrm{kgBB} / \mathrm{hari}$. Pada pemeriksaan rerata jumlah sel busa pada kelompok perlakuan 2 memiliki jumlah $13.82( \pm 8.34)$ sel busa, hasil ini memperlihatkan terdapat penurunan jumlah sel busa dibandingkan dengan jumlah sel busa pada kelompok kontrol positif. Ekstrak biji ketumbar dosis $500 \mathrm{mg} / \mathrm{kgBB} / \mathrm{hari}$ mampu memberikan perbaikan terhadap jumlah sel busa pada lesi aterosklerosis di aorta abdominalis tikus putih.

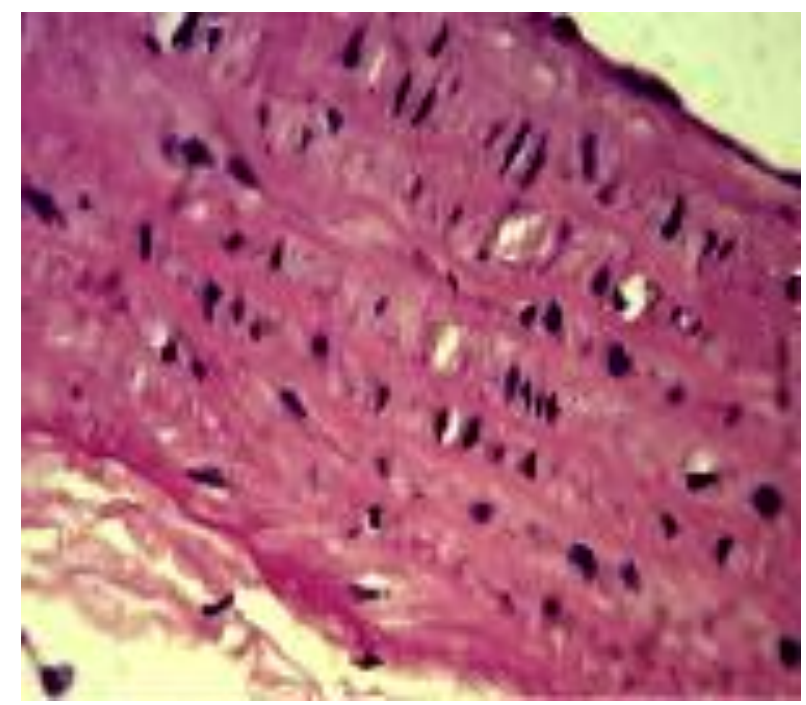

Gambar 5. Hasil Sajian Histopatologis Aorta Abdominalis Kelompok Perlakuan 3 Menggunakan Pewarnaan Hematoksilin dan Eosin Dengan Perbesaran 400x

Sumber Gambar: Data Primer, 2020

Gambar 5 merupakan kelompok perlakuan 3 yang diberikan ekstrak biji ketumbar dosis 700 $\mathrm{mg} / \mathrm{kgBB} /$ hari. Dari hasil perhitungan rerata jumlah sel busa pada kelompok perlakuan 3 yaitu 5.22 ( \pm 3.32$)$ mengalami penurunan rerata sel busa yang signifikan dibandingkan kelompok perlakuan lainnya bahkan hasil rerata tersebut hampir sama dengan rerata jumlah sel busa pada kelompok kontrol negatif yaitu $5.20( \pm 2.32)$. Penurunan jumlah sel busa yang signifikan dikarenakan ekstrak biji ketumbar memiliki kandungan antioksidan dan agen penurun profil lipid, hal ini sesuai dengan penelitian yang dilakukan oleh Aissaoui et al,. (2011) dikatakan bahwa ekstrak biji ketumbar dapat menjadi agen hipolipidemik termasuk menurunkan kadartrigliserida, LDL, dan dapat memiliki efek kardioprotektif. Ekstrak biji ketumbar memiliki berbagai kandungan seperti memiliki kandungan flavonoid, kuercetin, polifenol, tanin, karotenoid, dan vitamin $\mathrm{C}$ yang dapat mengurangi risiko pembentukan sel busa aterosklerosis. Kandungan flavonoid memiliki kemampuan sebagai penangkap radikal bebas dan menghambat oksidasi lipid (Zuraida et. al, 2017). Kuercetin mampu mencegah oksidasi LDL dengan menangkal radikal bebas dan ion-ion transisi sehingga kuersetin membantu dalam pencegahan penyakit seperti aterosklerosis (Arifin dan Ibrahim, 2018). Polifenol dapat melindungi dari kerusakan oksidatif serta menurunkan kerusakan oksidatif pada DNA dan lipid sehingga menurunkan risiko penyakit kardiovaskular dan kanker (Urquiaga dan Leighton, 2000). Polifenol mampu meningkatkan kadar HDL dan menurunkan LDL oksidatif (oxLDL), dan menurunkan kadar trigliserida (Cvejić et. al, 2017). Tanin mampu menghambat peroksidasi lipid melalui penghambatan siklooksigenase (COX) (Amarowicz, 2007). Karotenoid berfungsi sebagai peredam singlet oksigen dan deaktifator radikal bebas (Sayuti, 2015). Peran vitamin C sebagai 
pemulung (scavenger) superoksida dan radikal bebas lainnya, dapat mentransfer atom $\mathrm{H}$ atau oksigen untuk menangkal radikal bebas. Vitamin $\mathrm{C}$ dapat langsung bereaksi dengan anion superoksida, radikal hidroksil, oksigen singlet dan lipid peroksida (Iswara, 2009). Vitamin C memiliki kemampuan untuk melindungi dari peroksidasi lipid dengan bertindak sebagai pemungut/penghilang ROS dan mereduksi 1 elektron dari radikal hidroperoksil lipid melalui siklus redoks vitamin E. Vitamin $\mathrm{C}$ merubah produk peroksidasi lipid menjadi produk vitamin CLPO yang tidak reaktif (Pehlivan, 2018). Dalam penelitian Hillstrom, Yacapin-Ammons dan Lynch (2018) menunjukkan peran penting untuk vitamin $C$ dalam mencegah oksidasi lipid dalam HDL dan menjaga kemampuan kardioprotektif untuk menghambat modifikasi aterogenik (seperti : oksidasi LDL), sehingga pemberian ekstrak biji ketumbar diharapkan dapat memperbaiki pembentukan lesi aterosklerosis. Oleh karena itu, kemampuan ekstrak biji ketumbar sebagai antioksidan dan memperbaiki profil lipid dapat mencegah pembentukan aterosklerosis yaitu sel busa, pada pemberian dosis ekstrak biji ketumbar $700 \mathrm{mg} / \mathrm{kgBB} / \mathrm{hari}$ mampu menimbulkan penurunan jumlah sel busa yang signifikan.

\section{KESIMPULAN DAN SARAN}

\section{Kesimpulan}

Berdasarkan hasil analisa dan pemba-hasan penelitian pemberian ekstrak biji ketumbar didapatkan kesimpulan terdapat perbaikan jumlah sel busa yang paling efektif pada pemberian ekstrak ekstrak biji ketumbar $700 \mathrm{mg} / \mathrm{kgBB} /$ hari lebih efektif untuk mengurangi jumlah sel busa aterosklerosis aorta abdominalis pada tikus putih model hiperkolesterolemia diabetes dibandingkan dosis ekstrak biji ketumbar $300 \mathrm{mg} / \mathrm{kgBB} / \mathrm{hari}$ dan $500 \mathrm{mg} / \mathrm{kgBB} / \mathrm{hari}$.

\section{Ucapan Terima Kasih (Acknowledgement)}

Penulis mengucapkan terimakasih kepada Dr. dr. Maria Selvester Thadeus, M.Biomed dan dr. Retno Yulianti, M.Biomed telah memberikan saran, bantuan, dan bimbingannya. Terimakasih kepada Departemen Farmakologi dan Terapi Fakultas Kedokteran Universitas Padjajaran, Bandung dan Departemen Histologi dan Patologi Anatomi Fakultas Kedokteran UPN Veteran Jakarta atas kesediannya digunakan sebagai tempat penelitian.

\section{REFERENSI}

Aissaoui, A, Zizi, S, Israili, Zafar, H, Lyoussi, B. (2011). Hypoglycemic and hypolipidemic effects of Coriandrum sativum L. in Meriones shawi rats. Journal of Ethnopharmacology Elsevier, 137(1), 652-661.

Amarowicz, R. (2007). Tannins: The new natural antioxidants. European Journal of Lipid Science and Technology, 109(6), 549-551.

Arifin, B. dan Ibrahim, S. (2018). Struktur, Bioaktivitas Dan Antioksidan Flavonoid Structure, Bioactivity and Antioxidan of Flavonoid. Jurnal Zarah, 6(1), 21-29.

Bhatt, H., Saklani, S. and Upadhayay, K. (2016). Anti-Oxidant And Anti-Diabetic Activities Of Ethanolic Extract Of Primula Denticulata Flowers. Indonesian Journal of Pharmacy, $27(2), 74$.

Budiman, B., Sihombing, R. dan Pradina, P. (2017). Hubungan Dislipidemia, Hipertensi Dan Diabetes Melitus Dengan Kejadian Infark Miokard Akut. Jurnal Kesehatan Masyarakat Andalas, 10(1), 32.

Cvejić, J, Krstonoŝić, MA, Bursác, M, Miljić, U. (2017). Polyphenols Nutraceutical and Functional Food Components: Effects of Innovative Processing Techniques, 1st edn. 
Serbia: Academic Press, 203-258.

Frankilawati, D. A. M. (2013). Hubungan Antara Pola Makan, Genetik Dan Kebiasaan Olahraga Terhadap Kejadian Diabetes Melitus Tipe II DI Wilayah Kerja Puskesmas Nusukan, Banjarsari. Universitas Muhammadiyah Surakarta, 19-24.

Günenç Beşer, C, Karçaaltincaba, M, Çelik, H, Başar, R. (2016). The prevalence and distribution of the atherosclerotic plaques in the abdominal aorta and its branches. Folia Morphologica Poland, 75(3), 364-375.

Hillstrom, R. J., Yacapin-Ammons, A. K. dan Lynch, S. M. (2018). Vitamin C Inhibits Lipid Oxidation in Human HDL. The Journal of Nutrition, 133(10), 3047-3051.

Ismawati, Oenzil, F, Yanwirasti, Y, Yerizel, E. (2017). Analisis Konsentrasi Low Density Lipoprotein teroksidasi Serum pada Tahapan Aterosklerosis. Jurnal Kedokteran Brawijaya, 9(4), 348-352.

Iswara, A. (2009). Pengaruh Pemberian Antioksidan VItamin C dan E terhadap Kualitas Spermatozoa Tikus Putih Terpapar Allethrin. Universitas Negeri Semarang, 1-68.

International Diabetes Federation. (2017). IDF Diabetes Atlas.

Kementrian Kesehatan Pemerintah RI. (2014). Infodatin : Situasi Kesehatan Jantung. Pusat Data dan Informasi Kementerian Kesehatan RI, 1-8.

Kharroubi, A. T. (2015), Diabetes mellitus: The epidemic of the century, World Journal of Diabetes, 6(6), 850.

Kristiawan P. A. Nugroho, R. Rr Maria Dyah Kurniasari, T. N. (2019). Gambaran Pola Makan Sebagai Penyebab Kejadian Penyakit Tidak Menular, Universitas Kristen Satya Wacan, $15-23$.

Lathifah, N. L. (2017). Hubungan Durasi Penyakit Dan Kadar Gula Darah Dengan Keluhan Subyektif Penderita Diabetes Melitus The Relationship Between Duration Disease And Glucose Blood Related To Subjective Compliance In Diabetes Mellitus, Jurnal Berkala Epidemiologi, 231-235.

Lilly, LS. (2011). Pathophysiology of Heart Disease: a Collaboration Project Of Medical Students Faculty. Baltimore: Wolters Kluwer/Lippincott Williams \& Wilkin.

Msaada, K, Jernia, M, Salem, N, Bachrouch, O, Sriti, J, Tammar, S, Bettaieb, I, Jabri, I, Kefi, S,

Limam, F, Marzouk, B. (2017). Antioxidant activity of methanolic extracts from three coriander (Coriandrum sativum L.) fruit varieties, Arabian Journal of Chemistry King Saud University, 10, S3176-S3183.

Nani, Y. (2018). Analaisis Penggunaan Simvastatin dan Atorvastatin berdasarkan Peresepan Obat Rawat Jalan dengan Metode ATC/DDD. Universitas Muhammadiyah Malang, 428.

Olivia Enggar, P. (2017). Pengaruh Ekstrak Daun Kelor (Moringan oleifera L) Terhadap Malondialdehid Hati Tikus Jantan Strain Wistar Hiperkolesterol, Universitas Muhammadiyah Malang, 5-17.

Parseyan, N. (2012). The Effect of Coriander Seed Powder Consumption on Atherosclerotic and Cardioprotective Indices of Type 2 Diabetic Patients. Iranian Journal Of Diabetes and Obesity, 4(2), 86-90.

Pehlivan, F. E. (2018). Vitamin C: An Antioxidant Agent, IntechOpen, 1, 13.

Primanda, R. C. (2017). Pengaruh Pemberian Minyak Atsiri Biji Ketumbar (Coriandrum sativum) Terhadap Pertumbuhan Cancida albican (Penelitian Secara In Vitro'. Universitas Muhammadiyah Malang, 3-21.

Sari, R. P. dan Rahayuningsih, H. M. (2014). Pengaruh Pemberian Jahe Merah (Zingiber Officinale Var Rubrum) terhadap Kadar Kolesterol Total Wanita Dislipidemia. Journal of Nutrition College, 3, 798-806. 
Sayuti, K. (2015). Antioksidan Alami dan Sintetik. Padang: Andalas University Press.

Sorimuda, S. (2018). Hubungan Dislipidemia Dan Hipertensi Terhadap Kejadian Penyakit Jantung Koroner Pada Anggota Tentara Nasional Indonesian (Tni) < 40 Tahun Di Rumah Sakit Tk Ii Putri Hijau Medan. Jurnal Muara Sains, Teknologi, Kesehatan, dan Ilmu Kesehatan ,2(1), 291-298.

Tappi, V. E., Nelwan, J. E. and Kandou, G. D. (2019). Hubungan Antara Aktivitas Fisik Dan Riwayat Keluarga Dengan Kejadian Penyakit Jantung Koroner Di Badan Layanan Umum Rumah Sakit Umum Pusat Prof. Dr. R. D. Kandou Manado. Kesmas, 7(4).

Tianandari, F. and Rasidah, R. (2018). Uji Sitotoksik Ekstrak Etanol Buah Ketumbar (Coriandrum Sativum Linn) Terhadap Artemia Salina Leach Dengan Metode Brine Shrimp Lethality Test (BSLT). AcTion: Aceh Nutrition Journal, 2(2), 86.

Urquiaga, I. and Leighton, F. (2000). Plant Polyphenol Antioxidants and Oxidative Stress. Biological Research, 33(2), 55-64.

Yulianty, O, Sudiastuti, dan Nugroho, A. (2015). Efek Ekstrak Biji Ketumbar ( Coriandrum sativum L .) terhadap Histologi Pankreas Mencit ( Mus musculus L .) Diabetik Aloksan. Universitas Mulawarman, 12-16.

Zuraida, Z, Sulistiyani, Sajuthi, D, Suparto, I. (2017). 'Fenol, Flavonoid, Dan Aktivitas Antioksidan Pada Ekstrak Kulit Batang Pulai (Alstonia scholaris R.Br). Jurnal Penelitian Hasil Hutan, 35(3), 211-219. 
EFEKTIVITAS PEMBERIAN EKSTRAK BIJI KETUMBAR

TERHADAP GAMBARAN SEL BUSA ATEROSKLEROSIS

AORTA ABDOMINALIS TIKUS HIPERKOLESTEROLEMIA

DIABETES 